\title{
香りの魅力を探り伝えるための取り組み Efforts to Explore and Convey the Appeal of Scents
}

\author{
國枝 里美立命館大学 \\ Satomi KUNIEDA Ritsumeikan University
}

Keywords : Flavor, Fragrance, Sensory and consumer science, Sensory profiling techniques

\section{1. はじめに}

香り (匂い) の質的特徵を他人と共有することは, 食品や 香粧品などの製品を扱う際に大変重要となる，特に，喏好品 と呼ばれる珈琲や紅茶などの飲料, あるいは香水などは, その芳香の特徵が直接的に製品の価值と結びつく，そのため, 製品開発などの場面では, 製品の芳香の特徵やその喏好に 関する情報を関係者で共有することが必要となる.

一方で，香りに対する表現を共有することはなかなか難しい． 開発者などの専門家同士であっても同じものに対して, 同程度の 感覚強度とその特徵を示すことができるようにトレーニングをす る. 消費者では, 当然, その香りを適切に表現することは難しい. 人々の香りの特徵や嗜好を把握するためには, 物と人の反応 の両方を正しく理解しようとすることが重要である.

ここでは, 香りの官能評価や嗜好調査, 生理計測の例を 挙げて, 香りの特徴の示し方, 香りの魅力の伝え方について 考察する.

\section{2. 香気成分の特徵表現を統一する}

例えば，紅茶のフレーバーについて記述的な評価を行う ときに, その特徴となる香りと味の要素を分解して, その 各要素の主観的強度をもって評定する, そのため, 各要素 に分解できること, 分解した要素の表現が適切であること が必要となる。紅茶は身近な飲料であっても，一般的な 消費者では, 代表的な紅茶の各々の特徴を表現する機会は 少ない.このため, 紅茶の代表的な種類とその特徴を学び, 要素分解された個々の特徵の有無を判断できるように卜 レーニングを行う必要がある.

このために, 評価用語のための風味表現の辞書があれば, これらの中にある表現をトレーニングすればよい.この 風味表現の辞書となるものとして, 近年では多くの食品・ 飲料のフレーバーホイールが作成されている.

専門家が自らの経験（機器分析と自己の感覚表現）から, 必要な情報を共有するために, さまざまな試料となる食品や 飲料の特徵表現をあげて，これを擦り合わせる。評価用語と なる共有するための言葉を絞り込み, それぞれの言葉には 具体的なリファレンスもつけることで, その特徵がどのよう な質を有するものかがわかる.
それをより多くの人が理解し, 使用することで, 例えば, 紅茶のフレーバーの特徴について, 専門家だけでなくより多く の人で表現を共有することができるようになるのである $[1]$.

風味評価では, 通常, 消費者の反応は, 紅茶の味がするが… というものの, フローラル, フルーティ, グリーン, 甘い, 渋い, という特徵が想像するほどは簡単には出てこない. 特徵を どのように表現してよいのかわからないためである. しかし, トレーニングを重ねていくと, 特徵を表現する語彙も増える し，わずかな特徵の違いを見つけやすくもなる．試料間のどこ に違いがあるのかがわかるようになる，身近な紅茶が複雑な フレーバー成分から構成されていることを学ぶことにも通じる.

企業の多くは, 記述的分析を用いて, 自社製品や競合他社 の製品のフレーバーについて官能評価を行い, 製品の改善や 市場にある様々な他社製品の動向の把握の一助としているた め, 複雑なフレーバー(香りと味), 口当たりやテクスチャー などの属性を基本的な単位の特徵に分解して, その特徵を 共有することができれば, 様々な試料について共有する感覚 表現で特徴の違いを表現, 共有することができる.

ここに，コーヒーのフレーバーホイールを示す（図1) [2]. これは, World Coffee Researchの Sensory Lexicon (2017) を 基に, SCAA (Specialty Coffee Association of America) で 作成されたものである. 最適な抽出基準や焙煎などの教育と もに，この表現を多くの人たちが学ぶことで，コーヒーの 品質の低下を防ぎ，品質の良い個性豊かなコーヒーを市場に 出そうという試みに用いられている。

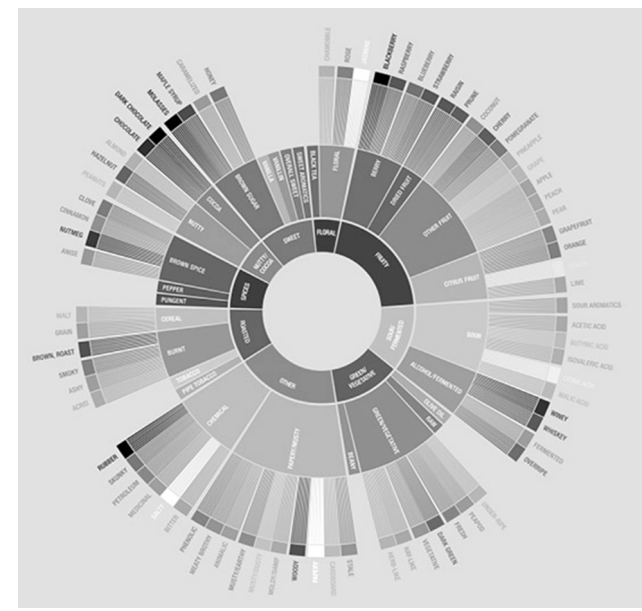

図1 SCAAフレーバーホイール 
表1 Sensory Lexiconの例 (一部抜粋)

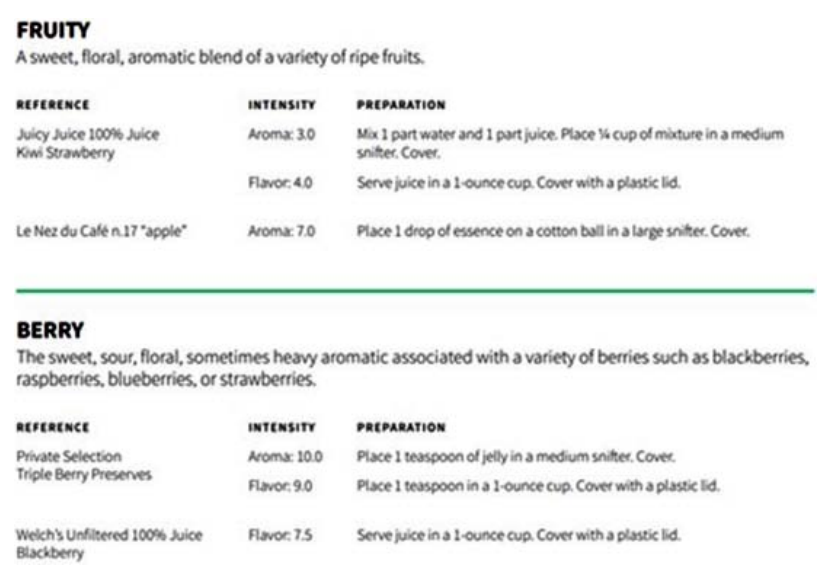

Sensory Lexiconには特徵を表現する各用語について, 誰も が同じものを想定できるように関連するカテゴリーとリファ レンスと各強度に対する調整方法が記されている（表1).

我々も鰹節などのだしの風味や茶類全般の風味の特徵を 表現するために，その評価用語をフレーバーホイールとし て作成している $[1,3]$ が, 全用語を絞り込む過程とともに リファレンスの作成に苦労した。その特徵香が強い試料を 実際に選び出すことができるかどうかなど，最終的な用語 決定に至るまでに何度も関係者で評価および確認試験を実 施した。茶類の風味評価では, この用語とリファレンスに よって, 関係者は, 直接, 茶類の特徴的な風味を確認して 情報共有を行うことができる.

このように記述的なプロファイルをしっかりと把握し，これ に消費者の嗜好調査データや生理計測デー夕を組み合わせる ことで，現行製品の改良や新製品の方向性を決定するための データとなる.

\section{3. 香りに対する嗜好性の検討}

食品・飲料に対する美味しさは，栄養素として必要なものを 身体が欲する生理的な欲求を満たすことにあるだけでなく, 文化的に受容されるものや現代人にあっては情報による価值に よって誘発されるものもある(伏木, 2003). これらの個々の 要因はさらに複雑に絡み合い, 我々は美味しいと感じている.

呈味物質には生理的な効果を予見させるシグナルとしての役 割があり，我々にはそれを認知する能力が備わっている [4].

例えば，糖質はカロリーや血糖のシグナルとして，我々 は甘く好ましい味と感じるし，苦味はアルカロイド類など, 危険な異物であるだろうことを予想させる。この合理的な 能力は生得的な反応としてみることができる.

一方, 食品の美味しさは, 各感覚器から受け取った食品の 情報（色, 形などの外観, 味や香り, 温度, 食感など）は, 知覚や思考の中枢となる大脳皮質の各感覚野に伝えられる. 感覚野に伝えられた情報は, 大脳皮質連合野で, 安全な食べ物 か, 求めている栄養素が含まれているかなど判断される。
食品の情報と生理的な状態の情報は扁桃体で記憶や体験 など過去の情報と照合し,「快・不快」の感情を生み出す. 食品や飲料に含まれる芳香物質は数百もの種類が複合され， 非常に複雑であり, その組み合わさり方や濃度の変化が我々 に異なる質をもった香りとして認識させることも少なくない.

匂いに対する感覚の大きさや感度は, 物理的な刺激の量の 対数に比例するというフェヒナーの法則に従うが, これだけで は複雑な香りの特徵を説明することは難しい，混合された 成分のうち，闇上の成分だけが我々の感覚に作用しているわ けではないためである。そのため，ある種の芳香物質だけに 注目してその心理効果や生理効果を検討しても, その物質を 他の芳香物質と混合することによって結果的にその成分を検知 できないということもある。我々が匂い（香り）として認知して 心動かされるものは, 単一の成分の影響によるものとは必ずし も限定できるものではなく, 複雑に複合されることで創られる 芳香が我々の心理に影響をもたらす場合もまたあるのである.

例えば，視覚と嗅覚の知覚反応の相互作用については, 匂いの刺激の強度によって, 視覚刺激による影響の度合いが 異なることが色と匂いの提示による実験で示されている.

また，嗜好品の代表例として挙げられる香水では，ボトル デザイン (視覚情報) とその香りの質 (嗅覚情報)のイメージ の一致性を複数の香水を対象に消費者パネルに比較評価して もらい, ボトルの印象度と香りの印象度の一致性について 確認するといったことがされている [5]，この時，消費者 パネルはボトルの評価にも香りの評価にも評価用語を使うこ となく, 自分自身のイメージで平面上に各試料を付置して プロファイルを決定するというNapping という手法が適用さ れている.各自が付置した試料について基準試料からの距離 を測定し, その距離から多変量解析により分析する。

香りに対する印象については消費者で統一した評価用語を 用いて評価することが難しいこと，ボトルに対する印象と 香りに対する印象を同じ次元で解析しょうとするときに, 言葉を介さない評価方法は消費者パネルへの負担も少なく， 有効であると考えられる。

\section{TDS (Temporal Dominance of Sensations) に よる経時的な風味特徴の変化}

香りの成分のための機器分析装置である GCのスペクトル にみられる芳香成分間の量比と感覚強度差は必ずしも一致し ているわけではない. GC-Olfactory（匂い嗅ぎGC）を行い， 含まれている香りの成分の質とフレーバー強度に貢献度の 高い成分を見つけ出す方法や匂い質のキーと考えられる成分の 閾值やフレーバー強度を測定することで, 食品としての香りの中 の芳香物質の貢献度を検討することになる, 食品や飲料の 咀嚼, 嚥下後に口中で感じられる戻り香, すなわちレトロネーザ ルアロマについても, 機器分析による芳香成分の測定を行い, 実際の飲食にできるだけ近い状態を作り，芳香成分を我々が どのように感じているのかを検討する研究も進んでいる。 
特定の芳香物質に対する人の反応を見るだけでなく，その 香りが実際に人に提示される状態に近い試料でも確認実験を 行う必要があると考える.

消費者が喫食時に感じる風味の経時的な変化をみるため に開発されたのがTDS (Temporal Dominance of Sensations) である。これまで, 経時的な風味の特徴変化は, TI (Time Intensity）法が実施されてきた。これは，あるひとつの特徵 の経時的変化を確認するための方法であり, PC画面に映さ れたある特徵に対する感覚強度を指し示すモノサシ上で, 口に入れてから咀嚼をして飲み込むまでの時間（あるいは 飲み込んでからも感じなくなるまでのある一定時間）を示され たモノサシ上で自分が感じた強度を指し示し, その感覚強度 デー夕を取り込む.これに対し, TDSは, 複数（10項目以下 がよいとされる) ある特徽のどれが最も強く感じるのかを 一定時間の間, 選択する。 TI た分析型の集団に適しているといわれているのに対し， TDS は, 味わっている間にその都度最も強く感じた特徵を 6〜10項目程度の評価用語から選び出すため, 啫好型の集団 にも適用しやすいとされている [6].

図2にTDS曲線を示す.TIで扱うのは連続的でモナディッ クな経時データであるが, TDS の場合は, 出現順位を経時 的に追っている離散型データを扱う。TIではしっかりと トレーニングされて個人内のばらつきが安定している熟練 した分析型パネルで実施されることが多いが, TDSでは 各評価用語に対する判断が俊敏にできることが求められる.

ここで, 同一のコーヒーを容器を変えて消費者の代表と なる評価者に飲んでもらったときのTDSカーブを示す.

コーヒーはカップで飲む, カップに蓋をしてストローで

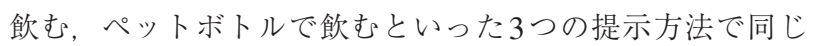
コーヒーのフレーバーの経時変化を確認した.

評価では, coffee, milk, sweet, sweetness, bitterness, sourness, full-bodyの7つの項目に注目にして, コーヒーを 一口飲んでから 70 秒の間, フレーバーが各項目のなかで最も 強く感じた項目を都度選んでもらった。結果を図3に示す。

この結果, 同じコーヒーであっても, カップで飲むときは コーヒーの香りが長い間しっかりと感じられるのに対し，

Data for one evaluation by one panellist

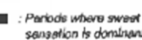

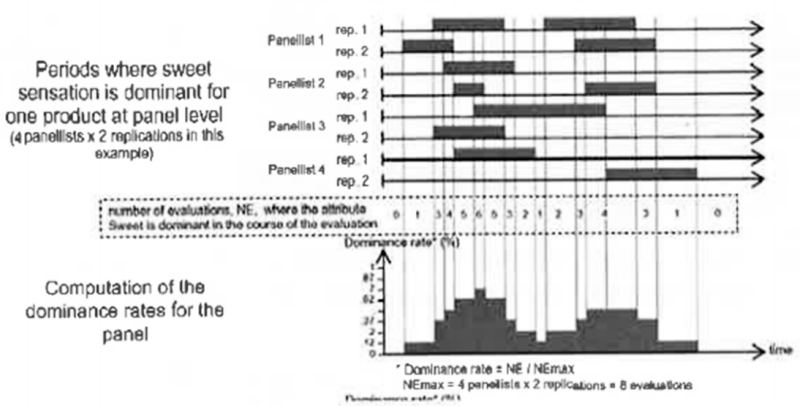

図2 TDS曲線の描き方

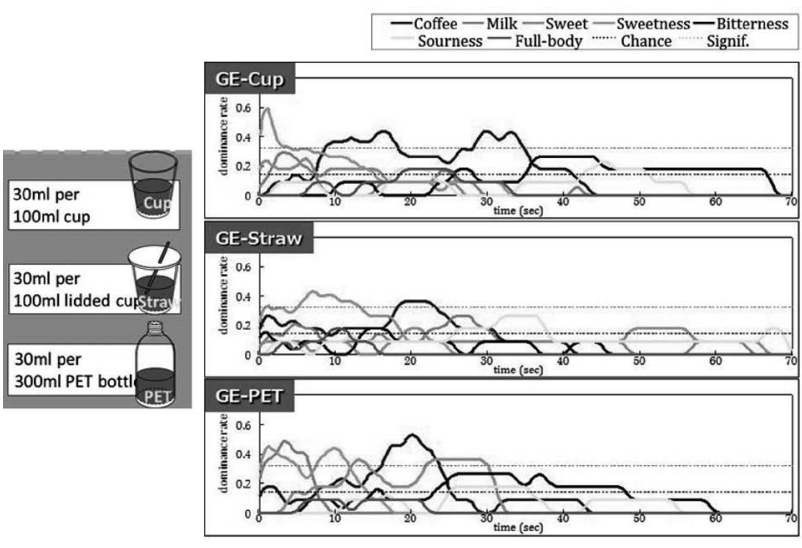

図3Ｃoffeeの飲み方の違いによるTDS曲線の違い

ストローで飲む，あるいはペットボトルの口から直接飲む 場合は, コーヒーの香りがしっかりと感じられる時間は 僅かであることが示唆された.

このように, TDSは, さまざまな食品の口腔内における 感覚変化を食べたときから飲みこみ，後味といわれる余韻 までのフレーバーの経時的な変化を確認するために，よく 用いられている。

\section{5. 匂いが行動にもたらす効果}

一般的な芳香療法では, リラクゼーション，ストレスの 軽減, 解消といった精神の健康を維持, 向上して, 病気を予 防する目的で用いられる [7]. 香りの生理心理効果の研究も 報告されている [8-10]. ローズ, ラベンダー, ペパーミン 卜など様々な精油を用いて, 疲労や不安の軽減, 瘦身効果, 作業効率など，自律神経系の活動への香りの作用を心拍変動 解析や抹消皮膚温, 脳波の事象関連電位の成分解析, fMRI やPETを用いた脳活動の解析など, 様々である.

これらの生体計測の結果は, 具体的な行動改善に反映され ることを期待しているものであるが, この香りによって行動 が改善されることを期待し，情意との関係を考えた研究とし て, 認知症の高齢者への音楽療法と徘徊を抑える試み, 言語 治療場面や言語学習に挑ける香りの応用がある [11].

幼児や認知症高齢者を対象とした場合では，言語による コミュニケーションが難しい，言葉を必要とする官能評価 と異なり, 香りによる行動変化をビデオ撮影などから確認 する方法も検討されている。

表 2 に示すのは，大学生における異文化言語の習得実験 の結果である。学習に香りを併用した場合と香りを併用し

表2 異文化言語習得への香りの効果

\begin{tabular}{|c|c|c|c|}
\hline & 正解 & 不正解 & 合計 \\
\hline 香りあり & 52 & 8 & 60 \\
\hline 香りなし & 36 & 24 & 60 \\
\hline 合計 & 88 & 32 & 120 \\
\hline
\end{tabular}


なかった場合の正解数 (不正解数) を比べると, 香りを併用 した場合の学習に扔いて, 大きく正解率が向上することが 確認された。

また，子供たちや高齢者に対する香りの効果は，香りの カルタで遊んでもらう様子や音楽療法で用いる楽器を使用 時に芳香するよう細工を施して, その楽器の使用時の様子を 撮影し，第三者によって子供や高齢者の表情を 10 秒ごとに 評価してもらい, 表情変化の推移を数量化することを試みて いる。これによって, 香りのカルタで遊ぶ子供の表情では, 楽しいことに加えて，自信を持ち，もっと遊びたいという 意欲的な様子が観察することができた，五感教育の中にこの ようなプログラムが組み込めたら，改めて身近にある匂い． 香りの大切さに気付くきっかけを作ることができるのでは ないだろうか.

これらの評価で問題とされるのは，評価数を増やすこと がなかなかできないことである。しかしながら，対象者の 行動を丁寧に確認することで自らの気づきに結び付くこと も少なくない，この方法であれば, 対象者自らも気づいて いない無意識な本音の部分に迫り洞察するコンシューマー インサイトの対象となる調查にも有益な情報をもたらすこ とが期待される.

\section{6. さいごに}

人に香りが与える効果について, 官能評価や調査を中心に 我々が実際に感覚器から得た香りの情報がどのような影響を もたらすものであるかをいくつかの事例をもとに記したが， 匂いを認知できるかどうかを検査するキットや匂いを覚える ためのキットなどがいくつか開発されている.

例えば，アルッハイマー型認知症やパーキンソン病などの 初期に匂いを同定する能力の低下が認められることから， 嗅覚同定能力を測定し，早期に発見する取り組みもある。 また，食品の品質保証の分析では，オフフレーバーを検知す ることも重要な分析のひとつであるが，そのオフフレーバー の中から事故の多い良く知られる香りを覚えるキットも販売 されている.

匂い・香りと人の関係をさらに丁寧に観察, 研究を重ね ていくことで, 感覚や快適性, リハビリテーション, 脳機能 など様々な研究に対して, さらに我々の生活に有益な情報が もたらされることを期待したい．

\section{参 考 文 献}

[1] 國枝里美, 松原均: 茶系飲料のフレーバークリエイション のための茶フレーバーホイール, 日本味と匂学会誌, 22(3), pp.479-482, 2015.

[2] Coffee Taster's Flavor Wheel, http://www.scaa.org/?d=scaaflavor-wheel\&page=resources (2018.4閲覧).

[3] 有富菜穂子, 東雅子, 岸幹也, 加太希哉, 國枝里美: 魚節だしおよび者干だしの官能評価用語の収集と整理, 日本官能評価学会誌, 14(1-2), pp.34-39, 2010.

[4] 伏木亨：おいしさの構成要素とメカニズム, 栄養学雑 誌, 61(1), pp.1-7, 2003.

[5]千田明, 國枝里美: 香水の容器と香りのイメージ適合 性に関する研究, 2011年度日本味と匂学会第45回大会, 日本味と匂学会誌，18(3)，pp.583-586，2011.

６６］國枝里美：最近の官能評価手法TDSに関する検討, Aroma research, 14(1), pp.29-35, 2013.

［7］マリア・リス・バルチン, 田邊和子(監訳), 松村康生(監訳)： アロマセラピーサイエンス, フレグランスジャーナル社, 2011.

[8]乾賢他：Osmanthus fragrans (キンモクセイ類)の香り はオレキシンレベルを低下させ摃食行動に影響を及ぼす, 日本生理学会大会発表要旨集, $2007(0), p .136,2007$.

[9] 元永千穂他：精油の抗肥満効果 - 肥満と心の関係に着 目したアプローチ, Aroma research, 8(2), pp.164-167, 2007.

[10] 大野洋美他：グレープフルーツの香りの吸入が課題 遂行に伴う集中力低下を防ぐ, Aroma research，8(2), pp.168-171, 2007.

[11] 神宮英夫 : 香りと情意との関係: 行動改善効果の可能性, 日本味と匂学会誌, 19(2), pp.157-162, 2012.

(2020年 12 月 4 日受理)

\section{著者紹介}

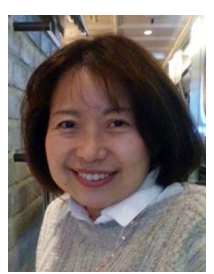

\section{國枝 里美}

1987年3月 日本大学理工学部工業化学科卒業. 同年 4 月 高砂香料工業株式会社入社. 総合研 究所にて, 官能評価, 匂いが人に与える効果 研究に従事. 2011年9月～2018年8月 日本味 と匂学会誌編集委員, 2018 年 立命館大学食 マネジメント学部教授。現在、に抒いか打り環境学会誌編集委員, 日本官能評価学会理事. 